\title{
Strategi Konvergensi Radio Sebagai Upaya Perluasan Pasar Audience dan Iklan (Studi Kasus Pada Swaragama Fm (101.7 Fm), Geronimo Fm (106.1 Fm), Dan Prambors Radio (102.2 FM/95.8 FM)).
}

\author{
Anindita Trinoviana \\ Program Studi Ilmu Komunikasi Universitas Islam Indonesia, Yogyakarta
}

\begin{abstract}
Abstrak
Penelitian ini menggunakan metode penelitian kualitatif dengan pengumpulan data melalui wawancara. Penelitian ini mewawancarai tiga radio yang aktif di media sosial di Yogyakarta, yakni Swaragama FM, Geronimo FM dan Prambors Radio. Hasil dari penelitian ini adalah ketiga radio melakukan strategi yang sama untuk memperluas khayalak yakni branding, promosi, positioning, riset, dan memanfaatkan teknologi saat ini. Dari segi pemasang iklan, ketiga radio menawarkan paket pemasangan iklan di media sosial maupun on air yang disebut dengan bandling. Konvergensi telah mempengaruhi ketiga radio ini dengan meluasnya jangkauan khalayak hingga mancanegara, yakni Eropa, Amerika, Hongkong, Thailand dan Rusia. Begitu pun dengan pemasangan iklan dari brand nasional. Sehingga, hasil yang didapatkan oleh ketiga radio, yakni meningkatnya jumlah pendengar dan pemasang iklan di era konvergensi media saat ini yang berpengaruh terhadap sumber pendapatan ketiga radio.
\end{abstract}

\section{Kata Kunci: Konvergensi Media, Perluasan Pasar Audience, Radio}

\begin{abstract}
This research uses qualitative research method with data collection through interview and documentation. This study interviewed three active radio stations in social media in Yogyakarta, namely Swaragama FM, Geronimo FM and Prambors Radio. The results of this research are the three radios doing the same strategy to expand the imagination of branding, promotion, positioning, research, and utilizing technology at this time. In terms of advertisers, the three radio packages offer advertising on social media and on air called the bandling. Convergence has influenced these three radios by extending the reach of audiences to foreign countries, namely Europe, America, Hongkong, Thailand and Russia. So even with the advertising of the national brand. Thus, the results obtained by the three radios, namely the increasing number of listeners and advertisers in the current era of media convergence that affects the revenue sources of the three radios.
\end{abstract}

Keywords : Media Convergence, Audience Market Expansion, Radio. 


\section{Pendahuluan}

Perkembangan teknologi yang begitu pesat mempengaruhi kebutuhan hiburan dan informasi di masyarakat. Hal ini tentu membuat media penyiaran yang memiliki fungsi sebagai media hiburan dan informasi merasa terancam oleh perkembangan teknologi tersebut. Media penyiaran karenanya harus merespon perubahan teknologi tersebut apabila ingin tetap bertahan di tengah masyarakat, diantaranya melalui penggabungan dengan teknologi internet, dan perluasan jaringan bagi media penyiaran lokal, terutama radio yang memiliki frekuensi pendek. Selain itu, kemunculan internet membuat media penyiaran memiliki pesaing untuk mendapatkan iklan, padahal iklan merupakan sumber pendapatan bagi media penyiaran tersebut. Namun, saat ini, banyak sekali iklan yang lebih memilih memasang di internet, website, ataupun media sosial. Oleh itu itu, munculah konvergensi media.

Radio merupakan salah satu media massa yang disukai oleh masyarakat Indonesia untuk mendapatkan hiburan maupun informasi. Selain itu, radio yang mempunyai karakteristik akrab, membuat pendengar merasa informasi dan hiburan yang diterima lebih spesifik. Oleh karena itu, radio tetap ada meskipun telah hadir media baru, internet. Bahkan, Nielsen Radio Audience Measurement mencatat pendengar radio masih menempati angka 38\%, hal tersebut menunjukan bahwa radio masih memiliki pendengar setia.
Pendengar radio rata-rata mendengarkan melalui telepon genggam, walaupun pengguna media baru memiliki angka lebih tinggi, yakni 40\% (Lubis, 2017).

Hal tersebut menunjukan bahwa radio masih bisa bersaing dengan media baru meskipun pengguna internet di Indonesia terus meningkat. Pada 2016, berdasarkan survei yang dilakukan oleh Asosiasi Penyelenggara Jaringan Internet Indonesia (APJII), pengguna internet mencapai 132,7 juta orang Indonesia yang diakses melalui perangkat genggam, dan smartphone (Widiartanto, 2016). Tentu saja, hal ini membuat radio memiliki tantangan tersendiri sebagai media massa untuk tetap bertahan.

Pada era media baru ini, radio harus beradaptasi dengan media baru. Hal ini dikarenakan masyarakat sangat mudah mengakses internet dalam segala aktivitas, didukung dengan kemajuan teknologi informasi yang serba cepat dan mudah. Oleh karena itu, saat ini, kita berada pada era konvergensi media, dimana masyarakat akan menggunakan satu perangkat untuk dua kegiatan dalam satu waktu, yakni mengakses internet dan mendengarkan radio. Radio dapat menggunakan media baru sebagai platform untuk lebih dekat dengan pendengarnya, bahkan akan terasa lebih mudah bagi pendengar untuk mencari informasi tentang radio kesukaan mereka.

Dalam konvergensi media, bukan sekadar tentang penyatuan media massa dengan media baru, tapi, dalam 
manajemen pun, akan ada beberapa yang berubah. Publikasi yang dilakukan oleh radio pun tentu akan memiliki perbedaan, interaksi yang dilakukan oleh radio dengan pendengar pun tentu berbeda setelah munculnya new media, dari telepon interaktif menjadi interaksi melalui media sosial seperti twitter, facebook, instagram, bahkan youtube. Selain itu, dampak konvergensi media adalah perluasan jaringan, dan perubahan pemasangan iklan dalam media tersebut. Hal ini dikarenakan media konvergensi merupakan bersatunya teknologi kmunikasi konvensional dengan komputer atau internet sekaligus menyebabkan perubahan radikal dalam penanganan, penyediaan, distribusi dan pemrosesan segala bentuk informasi, baik visual, audio, data, dan sebagainya (Preston dalam Romli, 2016 : 132). Akibatnya, media massa menjadi lebih kuat dan beragam dalam penyajian produk kreatifitasnya kepada khalayak. Namun di sisi lain, media harus dapat bersaing satu dengan yang lain untuk mempertahankan loyalitas khalayaknya. Dengan demikian, media massa harus mengikuti kemajuan teknologi informasi dengan menggabungkannya internet dengan media massa tradisional.

Perkembangan teknologi informasi yang begitu pesat menimbulkan adanya kebutuhan baru bagi masyarakat di era new media saat ini, yakni media sosial. Setiap lapisan masyarakat tentu mengetahui adanya media sosial, bahkan sebagian besar masyarakat Indonesia menggunakan media sosial. Hal ini dapat dilihat berdasarkan hasil survei yang dilakukan oleh Asosiasi Penyelenggara Jaringan Internet Indonesia (APJII), yakni 71,6 juta pengguna internet mengakses facebook, 19,9 juta pengguna internet mengakses dan menempatkan media sosial instagram di posisi kedua, dan terakhir 14,5 juta pengguna internet mengakses YouTube sehinggga menempatkan YouTube pada posisi ketiga (Hidayat, 2017). Oleh karena itu, fenomena ini dapat dimanfaatkan oleh media penyiaran terutama radio, terutama untuk perluasan pasar audience.

Yogyakarta, salah satu daerah yang memiliki platform radio streaming, yakni jogjastreamers.com, dimana para pendengar dapat mendengarkan programprogram radio Jogja dimanapun dan kapanpun. Pendengar dibebaskan untuk memilih saluran radio mana yang mereka pilih. Selain itu, beberapa radio di Yogyakarta mempunyai platform serta media sosial seperti twitter dan facebook sendiri untuk memberikan informasi tentang program acara, dan awal mula radio itu berdiri, bahkan interaksi antara pendengar dan penyiar dapat melalui media sosial pada saat ini.

Beberapa radio di Yogyakarta memiliki aplikasi sendiri di playstore yang dapat diunduh oleh pengguna android, diantaranya adalah Swaragama FM (101.7 FM), Geronimo FM (106.1 FM), Prambors FM (102.2 FM) dengan saluran Jogja 95.8 
FM. Hal ini tentu semakin memudahkan pendengar radio dimana pun mereka berada, dan, dengan adanya aplikasi ini, menjadi salah satu jalan sebagai perluasan pasar bagi industri radio. Konvergensi media juga dapat dijadikan sebagai perluasan jangkauan audience. Hal ini dikarenakan segmen dari ketiga radio tersebut merupakan anak muda, dimana anak muda akrab dengan perkembangan teknologi.

Ketiga radio ini, Swaragama FM (101.7 FM), Geronimo FM (106.1 FM), dan Prambors FM (102.2 FM), termasuk tiga saluran radio yang terkenal di kalangan anak muda Jogja (Retno, 2017) yang telah memiliki media sosial dan platform sendiri. Untuk radio Prambors yang memiliki radio unit di sembilan kota, masing-masing radio unit memiliki media sosial sendiri. Bahkan, ketiga radio tersebut, sebelum melakukan siaran, akan memberitahu pendengar siapa yang akan menjadi penyiar dan dalam program acara apa dalam live tweet di akun twitter. Dalam akun instagram, ketiga radio tersebut memberikan informasi berupa event yang ada di Yogyakarta, iklan dan memperingati hari-hari yang ada di Indonesia. Bahkan, terkadang, ketiga radio tersebut hanya sekadar menyapa pendengarnya melalui akun media sosial mereka.

$$
\text { Perluasan pasar audience bukan }
$$
saja pada pendengar, tapi dapat berpengaruh terhadap iklan yang masuk ke radio. Maksudnya adalah iklan di radio belum tentu hanya melalui siaran, tapi dapat berada di website maupun media sosial dari radio tersebut. Tentu saja, hal ini merupakan keuntungan tersendiri bagi stasiun radio tersebut dalam memperluas pasarnya.

Berdasarkan hal tersebut, penggunaan konsep captive market akan mendukung media penyiaran dalam era konvergensi media saat ini. Oleh karena itu, peneliti tertarik meneliti fenomena konvergensi media radio yang dilihat dari segi ekonomi dalam perluasan pasar audience di era new media.

Nicholas Negroponte dari MIT pada 1978 mengidentifikasi sebuah teori konvergensi, bahwa kombinasi industri media tradisional dengan industri komputer akan menciptakan tipe baru komunikasi (Biagi, 2010: 232). Untuk mengidentifikasi apa yang terjadi pada industri media, Negroponte membuat dua model industri media, sebagai berikut. 


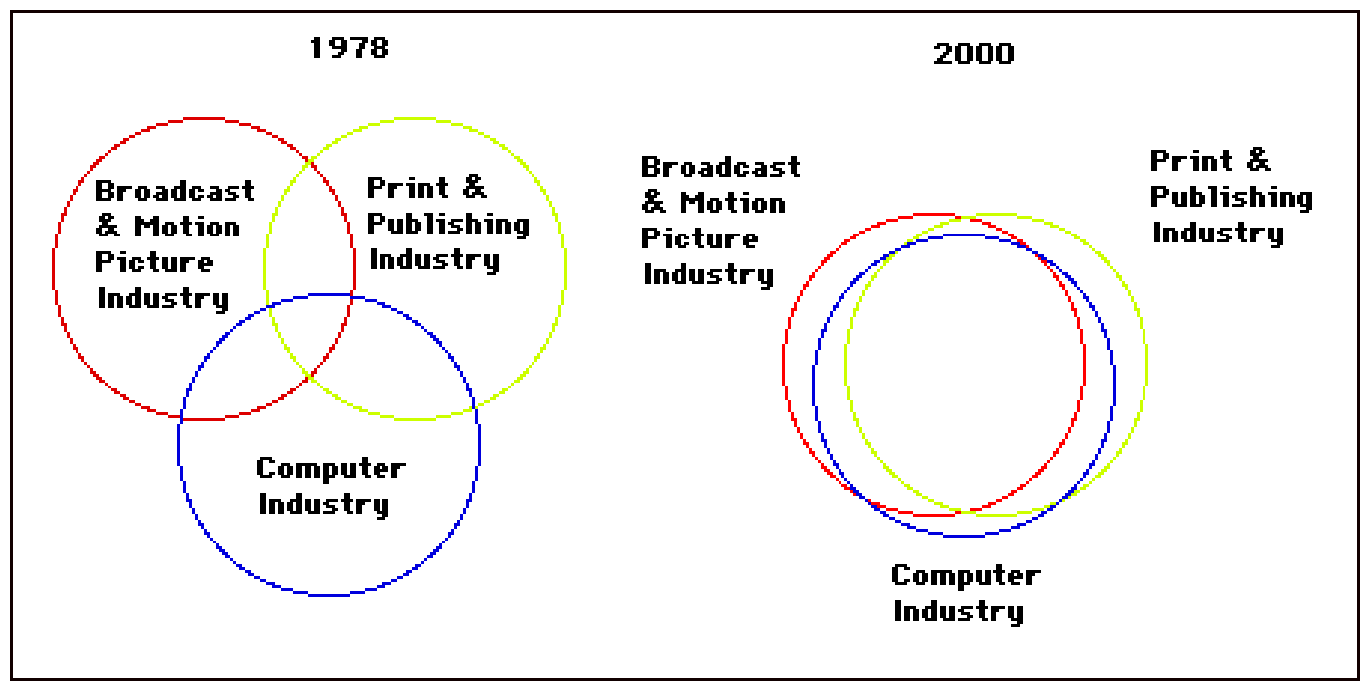

With these diagrams Megroponte made the case for the creation of a Media Laboratory at MIT.

\section{Gambar 1.1}

Model Industri Media Negroponte

Sumber : http://www.world.std.com/ mehopper/Media/Media.htm

Dua model industri media tersebut menunjukan industri media pada 1978 dan proyeksi industri media pada 2000. Dari gambar tersebut, dapat dilihat tiga segmen dari industri media yakni, cetak dan penerbitan, siaran dan gambar gerak, serta industri komputer. Model yang pertama, industri media pada tahun 1978, media massa dari cetak, siaran dan industri computer bergerak selaras. Pada 2000, ketiga media industri sepenuhnya tumpang tindih.

Dari prediksi Negroponte, model media industri pada 2000, saat ini telah terjadi, dimana media massa cetak dan penerbitan, siaran dan gambar gerak, serta industri komputer saling betumpang tindih, maksudnya ketiga industri tersebut sudah tidak bergerak di wilayahnya masing-masing, media cetak dan penerbitan dengan adanya industri komputer ditambah dengan adanya internet dapat merambah media siaran dan gambar gerak, begitupun sebaliknya. Oleh sebab itu, media massa memasuki era konvergensi media, salah satunya radio. Pada akhir abad ke-20, setiap industri media memiliki posisi yang sama untuk mengambil keuntungan dari perkembangan baru dan setiap industri media menerima manfaat dari konvergensi. Selain berpengaruh terhadap media massanya, dalam era konvergensi ini, juga berpengaruh terhadap bisnis dari industri media ini.

Dengan adanya internet yang dimanfaatkan oleh radio, dapat membuat radio memperluas jangkauan siaran. Hal 
ini dikarenakan adanya industri media yang bergabung dengan internet, sehingga membuat radio melakukan konvergensi media. Dalam hal ini, radio menggunakan internet untuk aktif di website, serta media sosial yang digunakan oleh khalayak sehingga arah komunikasi diantara khalayak dengan media massa pun saat ini terjalin secara interaktif, karena khalayak yang ada di media sosial merupakan khalayak yang aktif (Nasrullah, 2017:102).

Arah komunikasi tersebut merupakan salah satu perubahan yang dirasakan oleh radio saat ini. Selain arah komunikasi, ide konten juga mengalami perubahan agar bisa disiarkan dalam dua bentuk media, yakni media daring dan media konvensional.

Adanya kemunculan internet yang kemudian membuat internet menjadi medium massa baru yang mengintegrasi sistem pengiriman bagi media tradisional cetak, audio, video (Biagi, 2010: 13), dengan dibantu perkembangan teknologi yang begitu pesat, muncullah media digital yang mengkombinasikan teks, audio, video, menggunakan teknologi komputer (Biagi, 2010: 231).

Istilah media baru atau new media, menurut editor Handbook of New Media, terkai dengan teknologi informasi dan komunikasi dengan konteks sosial yang berhubungan yang menyatukan tiga elemen, yakni alat dan artefak teknologi; aktivitas, praktik dan penggunaan; dan tatanan sert organisasi sosial yang terbentuk disekeliling alat dan praktik tersebut (Mcquail, 2011 : 43). Oleh karena itu, kemunculan internet sebagai media baru membuat beberapa perubahan terhadap media tradisional. Perubahan tidak hanya terjadi pada media, tapi juga kepada masyarakat atau khalayak. Perubahan tersebut berupa kebiasaan mereka dalam menggunakan media dan kemajuan teknologi saat ini. Radio dalam melakukan perluasan pasar audience di era konvergensi media tentu saja memiliki strategi tersendiri, strategi merupakan tindakan yang bersifat incremental (senantiasa meningkat) dan terus menerus, serta dilakukan berdasarkan sudut pandang tentang apa yang diharapkan oleh para pelanggan di masa depan (Sugiya, 2012: 26). Ada empat bagian dalam strategi yang disebut dengan master strategy menurut Dan Schendel dan Charles Hofer Higgins (1985) (Salusu dalam Sugiya, 2012: 28 - 29), yakni enterprise strategy, corporate strategy, business strategy, dan functional strategy.

\section{Enterprise strategy.}

Strategi yang berhubungan dengan masyarakat yang merupakan kelompok di luar organisasi yang tidak dapat dikendalikan. Dalam strategi ini, terlihat hubungan antara organisasi dan masyarakat luar, sejauh interaksi yang akan dilakukan dapat menguntungkan organisasi. Dalam strategi ini, juga menampakkan bahwa organisasi bekerja dan berusaha untuk memberikan 
pelayanan yang baik terhadap tuntutan dan kebutuhan masyarakat.

\section{Corporate Strategy.}

Strategi yang berhubungan dengan misi organisasi yang juga sering disebut dengan grand theory. Strategi ini meliputi bidang yang digeluti oleh suatu organisasi. Bagaimana cara misi organisasi tersebut dijalankan baik organisasi bisnis, pemerintahan serta non profit juga penting. Hal tersebut memerlukan keputusan strategis dan perencanaan strategis yang selayaknya juga dipersiapkan dengan baik oleh setiap organisasi.

\section{Bussiness Strateegy.}

Strategi yang berhubungan dengan bagaimana cara mendapatkan pasar di tengah masyarakat, bagaimana menempatkan organisasi di hati para penguasa, para pengusaha, para donor dan sebagainya. Hal itu dimaksudkan agar memperoleh keuntungan-keuntungan stratejik yang juga mampu menunjang berkembangnya organisasi ke tingkat yang lebih baik.

\section{Fucntional Strategy.} Strategi pendukung dan untuk menunjang suksesnya strategi yang lainnya. Terdapat tiga jenis dalam strategi ini, yang pertama fungsional ekonomi yang meliputi fungsifungsi dimana memungkinkan organisasi hidup sebagai satu kesatuan ekonomi yang sehat. Kedua, fungsional manajemen yang meliputi fungsi-fungsi manajemen. Ketiga strategi isu stratejik yang memilikki fungsi utamanya adalah mengontrol lingkungan, baik situasi lingkungan yang sudah diketahui maupun belum diketahui ataupun yang selalu berubah.

Suatu perubahan yang dialami radio di era konvergensi media saat ini, sebagai upaya perluasan pasar audience, radio tentu akan menentukan strategi yang seperti apa untuk mendapatkan pasar audience ditengah bisnis media yang sangat ramai saat ini. Oleh karena itu, radio membutuhkan suatu strategi agar tetap di hati para pendengarnya dan mendapatkan jaringan pendengar yang baru. Dengan demikian, para pengiklan pun akan mengikuti, karena pengiklan melihat bagaimanaa radio tersebut di tengah masyarakat saat ini.

Pemasukan merupakan sumber kehidupan bagi industri media. Terdapat tiga sumber menurut John W. Dimmick dan Eric Rothenbuhler, yaitu capital (pemasukan iklan), types of content (jenis isi media yang disajikan oleh media), dan types of audiene (jenis khalayak sasarannya) (Haryati, 2012: 160). Dalam era konvergensi media, sumber pemasukan media pun bertambah melalui ongkos untuk online, pembayaran situs web dan subsidi dari pihak yang memproduksi (Mcquail, 2011 : 249). Dengan demikian, pasar dalam media dikelompokan menurut lini fundamental pembagian ekonomi antara pasar konsumen (consumer market) dan pasar iklan (advertising market). Dimana kelompok pasar konsumen untuk layanan dan produk media, sedangkan kelompok 
pasar iklan layanan dijual kepada para pengiklan dalam bentuk akses kepada khalayak (Mcquail, 2011: 249).

Hal ini dikarenakan pemasang iklan dan konsumen adalah tonggak keuangan bagi industri media karena khalayak yang berbeda menyediakan beragam pasar untuk produk konsumen (Biagi, 2010 : 19). Media, iklan dan khalayak saling ketergantungan dan tidak bisa dipisahkan. Pembuat iklan pun harus teliti dalam memilih medianya. Dalam radio, biro iklan membeli waktu yang lebih murah dan ruang pada radio lokal untuk menargetkan penonton yang spesifik dengan demografis. Namun, dengan adanya kemajuan teknologi yang begitu pesat, biro iklan pun akan paralel dengan perubahan pada media, teknologi, dan demografi (Biagi, 2010 : 280). Kemajuan teknologi yang ditandai dengan kemunculan internet, membuat biro iklan berpindah dari media massa tradisional, menjadi media internet. Hal ini disebabkan jaringan internet yang begitu luas memungkinkan menjangkau khalayak yang beragam dengan konten yang beragam pula, ditunjang dengan perekonomian yang mendukung. Internet sebagai media iklan dalam kapasitasnya secara akurat mengidentifikasi dan menjangkau banyak pasar yang berserakan bagi produk dan layanan tertentu (Mcquail, 2011: 251). Hal ini tentu membuat biro iklan mengharapkan respon yang baik dari khalayak. Dampak konvergensi media bukan saja terdapat pada perubahan alat teknologi dan manajemen, namun hal ini berdampak pada perluasan pasar audience dari media massa, terutama radio. Hal ini dikarenakan Audience atau khalayak saat ini mulai bergeser pola perilaku manusia karena adanya kemajuan teknologi internet (Romli, 2016 : 147). Selain menggeser pola perilaku manusia, kemajuan teknologi internet pun menyebabkan pesan dan arus balik dapat timbul secara cepat, karena pengirim dan penerima dapat berkomuikasi secara bersamaan dalam lingkungan digital saat ini (Biagi, 2010: 22). Tidak hanya itu, dengan adanya media internet yang digunakan oleh radio, para pengiklan pun mulai tertarik untuk memasang iklan di media online yang digunakan oleh radio karena produksi iklan dan pemaanfaatan media sosial cenderung membutuhkan biaya yang lebih murah (Nasrullah, 2017: 161).

\section{Metode Penelitian}

Penelitian ini menggunakan pendekatan konstruktivis dengan metode penelitian kualitatif. Penelitian kualitatif bermaksud untuk memahami fenomena apa yang dialami oleh subjek penelitian secara holistik dan dengan cara mendeskripsikan kata-kata dan bahasa, pada suatu konteks khusus (Moleong, 1989: 6). Dalam penelitian ini, peneliti berusaha untuk mengungkapkan fenomena konvergensi media dari segi ekonomi, yakni perluasan pasar audience atau captive market. 
Dalam pengambiilan data, peneliti menggunakan purposive sampling. Dimana purposive sampling ini kriteria narasumber berdasarkan tujuan penelitian untuk mendapatkan hasil yang sesuai dengan penelitian ini, selain itu, biasanya teknik pengambilan data purposive sampling dipilih ketika peneliti mengutamakan kedalaman data (Kriyantono, 2007: 154). Dengan narasumber penelitian ini adalah pengurus dari Swaragama FM, Geronimo FM, dan Prambors Radio (Pusat dan Jogja). Pengambilan data ini dilakukan selama dua bulan dengan metode wawancara tak terstruktur yang disebut juga sebagai wawancara mendalam, intensif kualitatif dan wawancara terbuka yang dimana susunan pertanyaannya dapat disesuaikan dengan karakteristik responden (Mulyana, 2001: 180).

\section{Analisis dan Pembahasan}

\section{Konvergensi Media}

Untuk beradaptasi dengan kemajuan teknologi saat ini, yakni internet. Radio menggabungkan media konvensional dengan media internet, yang disebut dengan konvergensi media. Ketiga radio ini telah melakukan konvergensi media sudah cukup lama, seperti Swaragama yang telah memulai sejak tahun 2002 mulai mengenal media sosial, dan mulai tahun 2010 mulai kearah serius. Prambors Radio mulai serius mengtur media sosial baru tahun 2014, sedangkan Geronimo dalam melakukan konvergensi media sejak tahun 2010 dan mengalir dengan apa adanya. Ketiga radio ini menggunakan bentuk dan konten media sosial yang sama, ketiga radio ini menggunakan website, streaming, aplikasi mobile phone, media sosial, dan social messenger (whatsapp), namun, Prambors Radio tidak aktif melalui social messenger. Isi yang ditampilkan ketiga radio tersebut pun memiliki tema yang sama, yakni program on air radio, kuis, iklan, dan memperingati hari besar di Indonesia. Dengan adanya konvergensi media dengan internet, saat ini, arah komunikasi yang dirasakan oleh ketiga radio dengan pendengar menjadi lebih interaktif. Hal ini dirasakan oleh Prambors dan Swaragama ketika menggunakan fitur live instagram, sedangkan Geronimo merasakan melalui adanya chat by whatsapp antara pendengar dan penyiar.

\section{Latar dan Tujuan}

Dalam melakukan konvergensi media, ketiga radio memiliki alasan dan tujuan yang serupa. Dari segi alasan, ketiga radio ini melakukan konvergensi media dikarenakan pendengar dan perkembangan zaman. Pendengar yang telah menggunakan media sosial, adanya kebutuhan pendengar akan beberapa fungsi teknologi yang baru, penyesuaian zaman, dan bertahan akan perkembangan zaman merupakan alasan-alasan dari ketiga radio dalam melakukan konvergensi media saat ini. Tujuan yang ingin dicapai oleh ketiga radio pun serupa, interaksi dan 
mendekatkan diri dengan pendengar menjadi tujuan bagi ketiga radio ini. Oleh karena itu, ketiga radio ini melakukan konvergensi media.

\section{Strategi Radio}

Strategi radio dalam melakukan konvergensi media ini, dibagi menjadi dua bagian strategi, yairu perluasan pendengar (audience) dan perluasan iklan. Dari segi perluasan pendengar, ketiga radio ini memiliki strategi yang serupa dan berkaitan, seperti Swaragama FM, dan Geronimo FM. Kedua radio ini melakukan strategi dengan branding kepada khalayak, namun, Geronimo FM ini melakukan branding dengan cara pendekatan dengan pendengar, positioning dan promosi. Prambors Radio dan Swaragama FM, melakukan riset sebagai strategi perluasan audience. Tidak hanya itu, bagi Prambors Radio, konsisten atas apa yang telah disiarkan menjadi salah satu strategi untuk memperluas pendengar.

Dari perluasan iklan, ketiga radio ini memiliki strategi yang sama, yakni berupa bandling (paket) iklan di media online dan saat on air. Namun, bagi Geronimo FM selain bandling, meyakinkan pihak principal bisa menjadi salah satu strategi. Begitu pun dengan Prambors Radio yang merasa konsisten dan friendly juga menjadi salah satu strategi untuk memperluas jaringan pengiklan di radio mereka. Dilihat dari berbagai strategi dalam melakukan perluasan pendengar maupun pengiklan, strategi dari ketiga radio ini dapat dimasukan kedalam Master Strategy menurut Dan Schendel dan Charles Hofer Higgins.

\section{Dampak dan Hasil Konvergensi}

Dalam melakukan konvergensi media, dampak yang dialami ketiga radio ini dibagi menjadi dua, dampak terhadap khalayak (pendengar) dan dampak terhadap pengiklan. Dampak terhadap pendengar, salah satunya bagi ketiga radio ini adalah meluasnya wilayah pendengar mereka saat ini. Selain itu, ketiga radio ini merasakan dampak yang berbeda-beda, dari Swaragama FM merasa feedback dari pendengar terasa lebih cepat oleh penyiar saat ini. bagi Geronimo FM konten obrolan menjadi lebih global, tidak melulu membahas lokal, tetapi dapat berupa nasional bahkan internasional. Sedangkan menurut Prambors Radio, image radio menjadi semakin lebih kuat di kalangan khalayak, namun untuk Prambors Radio unit Jogja, konvergensi media melalui media sosial dapat memperkenalkan radionya terlebih dahulu.

Dampak terhadap pengiklan, ketiga radio saat ini merasakan hal yang sama yakni adanya pemasangan iklan di media online (media sosial dan website) yang mereka miliki. Namun, bagi Swaragama FM sendiri, merasa dampaknya bukan hanya itu saja, namun saat ini pemasang iklan yang diterima oleh Swaragama tidak hanya berasal dari pelanggan lokal saja, 
namun juga nasional. Bagi Geronimo, dengan adanya iklan di media sosial, iklan yang mereka miliki bukan sekedar adlips dan spot, namun juga dapat berupa grafis maupun multimedia. Bagi Prrambors Radio yang memiliki siaran relay pada delapan unit radionya, saat ini iklan dapat disiarkan secara nasional. Dengan demikian, hasil yang didapatkan oleh ketiga radio ini terbagi menjadi dua bagian, hasil perluasan pendengar di era konvergensi media, dan hasil pemasangan iklan di era konvergensi media. Hasil dari perluasan pendengar, ketiga radio ini mendapatkan jangkauan wilayah yang lebih luas saat ini, namun untuk penambahan jumlah pendengar, bagi Swaragama FM tetap stabil, bagi Geronimo FM hanya lebih terukur, dan Prambors Radio merasa pendengar meningkat melalui web streaming yang mereka miliki.

Dari segi pemasangan iklan, Prambors Radio dan Geronimo FM sepakat bahwa jumlah pemasangan iklan setelah adanya bandling menjadi meningkat. Namun, hal ini berbeda dengan Swaragama FM, radio ini mengaku bahwa jumlah pemasangan iklan tetap stabil, namun dengan adanya bandling jangkauan wilayah pendengar menjadi lebih luas, dan segmen yang semakin melebar.

Apabila, dilihat dari segi hasil, sumber pendapatan ketiga radio ini meningkat setelah adanya konvergensi media yang dimanfaatkan sebagai upaya untuk memperluas pasar audience, dari segi perluasan pendengar, maupun perluasan pemasangan iklan. Hal ini dikarenakan, radio yang memiliki frekuensi terbatas menjadi terbantu dengan adanya konvergensi media yang lebih luas jangkauan frekuensi bagi ketiga radio ini, melalui streaming maupun media online (website dan media sosial) yang digunakan sebagai jendela untuk memperkenalkan ketiga radio ini kepada calon pendengar mereka, bahkan dapat digunakan untuk berinteraksi dengan para pendengar mereka, dimana pun pendengar berada.

\section{Penutup}

Salah satu media massa yang melakukan konvergensi media adalah Radio. Dimana radio yang menjadi objek penelitian adalah Swaragama FM, Geronimo FM dan Prambors Radio (Jakarta dan Unit Jogja). Perubahan yang terjadi pada radio pun bukan hanya sekedar alat dan manajemen yang berubah, namun perubahan ini pun terjadi pada segi ekonomi dari radio itu sendiri, yakni sebagai upaya perluasan pasar audience, dari segi pendengar radio dan para pemasang iklan. Hal ini dikarenakan wilayah pendengar radio yang pada awalnya terbatas.Walaupun banyak terjadi perubahan, radio masih tetap melakukan kebiasaan lama mereka dengan telpon interaktif, bahkan hingga saat ini, masih ada pendengar yang mendatangi stasiun radio itu sendiri. Padahal di era konvergensi media saat ini, interaksi yang 
dilakukan oleh radio melalui penyiar dengan pendengar menjadi lebih cepat karena adanya akun media sosial yang dimiliki oleh radio. Sehingga arah komunikasi diantara keduanya menjadi lebih aktif.

Dengan tiga objek penelitian tersebut, peneliti mengkomparasikan perubahan dan bentuk yang digunakan pada era konvergensi media, alasan dan tujuan melakukan konvergensi media, strategi yang dilakukan radio dalam upaya memperluas audience dan jangkauan pemasang iklan, apa saja faktor penghambat dan pendukung radio dalam melakukan upaya perluasan pasar audiencedan jangkauan pemasang iklan, serta bagaimana dampak dari konvergensi media dalam perluasan pasar audiencedan jangkauan pemasang iklan, serta adanya hasil yang diperoleh radio setelah melakukan perluasan pasar audience dan jangkauan pemasang iklan.

Dari hasil temuan penelitian, ketiga radio ini memiliki strategi serta faktor yang mendukung dan menghambat, dan pengaruh dari adanya konvergensi media yang dilakukan oleh radio dalam melakukan upaya perluasan pasar audience dan jangkauan pemasang iklan saat ini. Untuk lebih jelas, dapat dilihat sebagai berikut :

1. Strategi yang dilakukan oleh ketiga radio dapat dibedakan dari segi perluasan pendengar, dan perluasan pemasang iklan. Dari segi pendengar, ketiga radio melakukan riset, positioning, promosi, branding, dan konsisten dalam upayanya melakukan perluasan pasar. Hal tersebut dilakukan dengan cara sebagai berikut :

a. Riset dilakukan terhadap anak muda untuk mencari tahu apa yang disenangi, dan diinginkan oleh anak muda, serta untuk mengetahui apa yang sedang tren di kalangan anak muda.

b. Positioning, branding dan promosi dilakukan dengan melakukan pendekatan terhadap anak muda, mendekatkan dengan komunitas-komunitas anak muda, dan selalu hadir di kegiatan anak muda.

c. Konsisten yang dilakukan oleh Prambors Radio yang dilakukannya dengan cara selalu menayangkan konten yang sama di media sosial untuk membuat image yang kuat di kalangan pendengar.

d. Dari segi pemasangan iklan, radio menawarkan bandling, yakni menawarkan pemasangan iklan melalui dua media, yakni online dan konvensional. Bandlingmerupakan salah satu cara untuk memperluas pasar audience dari segi pengiklan. Strategi yang mereka lakukan pun masuk dalam Master Strategy menurut Dan Schendel dan Charles Hofer Higgins (1985).

2. Konvergensi media yang dilakukan radio melalui media daring seperti web streaming dan media sosial telah mempengaruhi radio dari segi pendengar dan pemasangan iklan. Dari segi pendengar radio, mereka 
mendapatkan perluasan wilayah pendengar hingga mancanegara, yakni Swaragama hingga Eropa dan Amerika, Geronimo hingga Hongkong dan Amerika, serta Prambors hingga Thailand, dan Rusia. Selain itu, dengan adanya media daring yang dimiliki oleh radio, seperti Swaragama merasakan mendapatkan feedback lebih cepat dari pendengar, Geronimo merasakan bahwa konten obrolan kini tidak melulu tentang lokal karena telah meluasnya wilayah pendengar saat ini, dan menurut Prambors, dengan adanya media online yang digunakan, Prambors merasa dapat membuat image semakin kuat dan meluas. Dari segi pemasang iklan, ketiga radio saat ini merasakan hal yang sama bahwa dengan adanya konvergensi media yang mereka lakukan dapat mempengaruhi wilayah pengiklan saat ini, karena pada saat ini ketiga radio saat ini tidak hanya melayani client lokal, tapi juga dari brand nasional.
Dari poin-poin yang telah disebutkan diatas, hasil yang diperoleh oleh ketiga radio adalah bertambahnya jumlah pendengar melalui web streaming dan bertambahnya jumlah pemasang iklan. Sehingga, hal ini berpengaruh terhadap sumber pendapatan ketiga radio saat ini,walaupun jumlah follower media sosial dari ketiga radio ini berbeda. Padahal ketiga radio ini memiliki bentuk konvergensi yang sama. Dari segi konten pun demikian, ketiga radio ini memiliki konten yang juga sama pada media sosial ketiga radio ini seperti kuis, peringatan hari besar, ilmu pengetahuan umum, dan juga informasi lainnya. Oleh karena itu, menurut ketiga radio, konvergensi dapat dimanfaatkan sebagai upaya perluasan pasar karena hal ini sangat menguntungkan bagi perusahaan media tersebut. 


\section{DAFTAR PUSTAKA}

Ardianto, Elvinaro., dkk. (2007) Komunikasi Massa Suatu Pengantar Ed. Revisi. Bandung: Remaja Rosdakarya

Baran, Stanley J. (2008). Pengantar Komunikasi Massa, Melek Media dan Budaya jilid 1 edisi 5 (Terj.). Jakarta: Erlangga.

Biagi, Shirley. (2010) Media/Impact Edisi 9: Pengantar Media Massa (Terj.). Jakarta: Salemba Humanika.

Kriyantono, Rachmat. (2007). Teknik Praktis Riset Komunikasi : Disertai contoh praktis riset media, Public Relations, Advertising, Komunikasi Organisasi, Komunikasi Pemasaran. Jakarta: Kencana Prenada Media Group.

McQuail, Denis. (2011). Teori Komunikasi Massa Mcquail Edisi 6 Buku 1 (Terj.). Jakarta: Salemba Humanika.

Moleong, Lexy J. (1989). Metodologi Penelitian Kualitatif. Rev.ed. Bandung: Remaja Rosdakarya.

Mulyana, Deddy. (2001) Metodologi Penelitian Kualitatif, Paradigma Baru Ilmu Komunikasi dan Ilmu Sosial Lainnya. Bandung: Remaja Rosdakarya.

Nasrullah, Rulli. (2015). Media Sosial Perspektif Komunikasi, Budaya dan Sosioteknologi. Bandung: Simbiosa Rekatama Media.

Romli, Khomsahrial. (2016) Komunikasi Massa. Jakarta: Grasindo.

\section{Jurnal Daring}

Epkamarsa, Hutama. "Perkembangan Konvergensi di Indonesia," Makalah non-seminar. Depok: UI, Januari 2014. dalam lib.ui.ac.id/file?file=digital/20368 947...Hutama\%20Epkamarsa.pdf (diakses tanggal 06 Mei 2017).

Harliantara. "Komunikasi Siaran Integrasi Media Konvensional dan Internet Pada Penyiaran Radio Swasta," Jurnal Komunikasi, Volume 10, Nomer 2 (April 2016), hal. 153-168, dalam

https://journal.uii.ac.id/index.php Ljurnal-

komunikasi/article/view/7601/663 5 (diakses tanggal o6 Mei 2017).

Haryati. "Ekologi Media di Era Konvergensi Media," Jurnal Observasi Vol. 10 No.2 (2012), hal. 147-167, dalam https://jurnal.kominfo.go.id (diakses tanggal o6 Mei 2017).

\section{Tesis}

Sugiya, Aritasius. (2012). "Strategi Tranformasi Konvergensi Media : Studi Kasus Grand Strategy Harian Kompas.” Tesis Magister, Fakultas Ilmu Sosial dan Ilmu Politik Universitas Indonesia, Jakarta dalam

lib.ui.ac.id/file?file=pdf/metadata20307883.pdf (diakses tanggal 20 Agustus 2017). 


\section{Internet :}

Lubis, Mila. "Radio Masih Memiliki Tempat di Hati Pendengarnya" artikel dalam http://www.nielsen.com/id/en/pr ess-room/2016/RADIO-MASIHMEMILIKI-TEMPAT-DI-HATIPENDENGARNYA.html, (diakses tanggal 25 April 2017).

Hidayat, Mochamad Wahyu. "3 Media Sosial Favorit Pengguna Internet Indonesia" artikel dalam http://tekno.liputan6.com/read/2 634027/3-media-sosial-favoritpengguna-internet-indonesia, (diakses pada tanggal o4 Mei 2017).
Widiartanto, Yoga Hastyadi "2016, Pengguna Internet di Indonesia Capai 132 Juta" artikel dalam http://tekno.kompas.com/read/20 16/10/24/15064727/2016.penggun a.internet.di.indonesia.capai.132.ju ta, (diakses pada tanggal 25 April 2017).

http://www.world.std.com/ mehopper/ Media/Media.htm (diakes pada tanggal o6 Mei 2017) 
Jurnal komunikasi, Volume 12, Nomor 1, Oktober 2017 